\title{
Consumer Satisfaction on Health Drinks With Specific to Horlicks in Vellore City
}

\author{
R. Sugumari
}

\begin{abstract}
Consumer is called as king in the market. The user's behaviour and perspective helps to find the powerful strategies and techniques by all the manufactures for securing abundant competitive advantagesin the market. In the LPG era people want tosurvive successfully so they need work for which energy and stamina are essential they acquired them from balanced health drinks. Good health indicates happy life and also an effective and efficient performance is not possible without good health. There are varieties of brands of health drinks but in this study only Horlicks is consider most and preferred by the consumers. The study generally concentrated on common price level, quality of the product, satisfaction level, public awareness and consumer preference of Horlicks.
\end{abstract}

Keywords : Consumer satisfaction, Consumer awareness, Horlicks and price.

\section{INTRODUCTION}

C ustomer satisfaction and happiness due to liberalization are on the agenda of top management. Gone are the days when you couldn't take a customer to a bar. Customers in India have been revealing what is happening around the world in recent times and demanding attention and value for their money. In India Industries Customer satisfy a medium and long-term strategy that does not come with the standard of service / goods with minimal costs by supplying customers services / goods by providing them entertaining to a point, the most important global market, where the price compared with the Tag Who, with minimum delay, to the survival and growth of such businesses do not trust. India is becoming the world's premier malt based drinks market. These drinks are traditionally consumed as milk substitutes and sold as nutritious drinks, mainly consumed by the elderly, young and the sick. White drinks and brown drinks are the two types of drinks. In all India sales East and South India are the largest markets for these beverages. Customer satisfaction is part of their experience, which exposes the behavior of a trader and how quickly services are delivered to the customer. This satisfaction may be related to various business phases such as marketing. Quality of products and services, answering customer questions, project completion and post-delivery services.

\section{REVIEW OF LITERATURE}

Journal of Advertising Researchindicates that "the most

Revised Manuscript Received on December 05, 2019

* Correspondence Author

R. Sugumari*, Assistant Professor In Commerce, Thiruvalluvar University College of Arts And Science, Arakkonam, Tamil Nadu, India. Email: Sugumariinba@gmail.com developing area of the marketing research is the Customer satisfaction and reasonable even in the context of Indian market economy with consumer as the central focus".

Latour, Steven A. and Naney C. Peat, "Conceptual and methodological issues in their study "Advances in consumer satisfaction research in consumer research". Failure to consider the extent to which a product or service fulfils a person's wishes have led to logical contradictions, such as predicting that the consumer will expect and expect poor performance.

Lele M.M and Sneth J.D in their article, "Customers' expectations regarding post-sale support, such as warranty accessories and other procurement services, can be a determining factor in customer satisfaction, especially for durable goods. After the sale, support is said to be the litmus test company that sees its customers.

\section{OBJECTIVES OF THE STUDY}

- To know the level of customer satisfaction towards the quality of Horlicks.

- To find out how frequently customer is purchasing the products.

- To study the customer satisfaction towards the price of the product.

- To analyse the source of information of the product.

\section{SCOPE OF THE STUDY}

Repurchase and recommendation of goods and services to others can be done only after consumers satisfactions by consuming these products. Quality assurance refers to a program for the systematic of quality are being met. This analysis is very helpful to identify the customer needs and to know whether they are satisfied or not with their product. This analysis would help in identifying the customer perspective towards Horlicks and to know the customer affordability, convenience, dependency and comfort ability.

\section{METHODOLOGY}

Sources of Evidence: Primary and Secondary data Tools of Acquiring Data: Questionnaire method Period of Collection: 30 days

Size of Sample: Fifty Respondents Method of Sample: Simple random Area of Study: Vellore city 


\section{Limitation}

Vellore is the only confined to this study. The findings cannot be generalized because the sample size is only 50 . Time is the major limiting factor.

\section{ANALYSIS AND INTEPRETATION}

Table - 1: Sources of Information

\begin{tabular}{|l|c|c|c|}
\hline \multirow{2}{*}{\multicolumn{1}{|c|}{ Source }} & \multicolumn{2}{c|}{ GENDER } & \multirow{2}{*}{ Total } \\
\cline { 2 - 3 } & Male & Female & \\
\hline Newspaper & 05 & 05 & 10 \\
\hline Television advertisement & 12 & 20 & 32 \\
\hline Children & 03 & 02 & 05 \\
\hline Doctor & 01 & 02 & 03 \\
\hline Total & 21 & 29 & 50 \\
\hline
\end{tabular}

$\mathbf{H}_{\mathbf{O}}$ : There is no association among gender and source of information of about the product.

$\mathbf{H}_{1}$ : There is an association among gender and source of information of about the product.

Calculation of ' $\mathrm{V}$ '

$\mathrm{V}=$ Row-1 xColumn-1

$=4-1 \times 2-1$

$=3 \times 1$

$\mathrm{V}=3$

Calculated Value $=1.28579$

Table value @ 5\% significant level=7.89

Conclusion: The Chi-Square value is less than the table value at $5 \%$ significant level. The already framed $\mathrm{H} 0$ is holding true. Hence is concludes There is no association among gender and source of information of about the product.

Table - 2: buying the same product due to increase in price

\begin{tabular}{|c|c|c|c|c|c|}
\hline \multicolumn{7}{|c|}{ Income } \\
\hline Particulars & $\begin{array}{c}\text { Below } \\
\mathbf{5 0 0 0}\end{array}$ & $\begin{array}{c}\mathbf{5 0 0 0}- \\
\mathbf{1 0 0 0 0}\end{array}$ & $\begin{array}{c}\mathbf{1 0 0 0 0}- \\
\mathbf{1 5 0 0}\end{array}$ & $\begin{array}{c}\text { Above } \\
\mathbf{1 5 0 0 0}\end{array}$ & Total \\
\hline Yes & 03 & 01 & 06 & 22 & 32 \\
\hline No & 04 & 05 & 07 & 02 & 18 \\
\hline Total & 07 & 06 & 13 & 24 & 50 \\
\hline
\end{tabular}

$\mathbf{H}_{\mathbf{0}}$ : The there is no valid difference between the income and buying the same product due to increase in price.

$\mathbf{H}_{1}$ : There is a significant relationship between the income and buying the same product due to increase in price.

Degree of freedom:

$$
\mathrm{V}=3
$$

Calculated value $=5.331$

Table value @5\% significant level = 7.81

Conclusion: The comparison between table value and
Chi-square value that the calculated Chi-square value is less. So, already framed $\mathrm{H} 0$ is true hence is concluded the there is no valid difference between the income and buying the same product due to increase in price.

Table - 3: Frequency of Purchase

\begin{tabular}{|l|c|c|c|c|c|}
\hline \multicolumn{7}{|c|}{$\begin{array}{c}\text { Income } \\
\text { purequency of } \\
\text { purchase }\end{array}$} & $\begin{array}{c}\text { Below } \\
\mathbf{5 0 0 0}\end{array}$ & $\begin{array}{c}\mathbf{5 0 0 0}- \\
\mathbf{1 0 0 0 0}\end{array}$ & $\begin{array}{c}\mathbf{1 0 0 0 0}- \\
\mathbf{1 5 0 0 0}\end{array}$ & $\begin{array}{c}\text { Above } \\
\mathbf{1 5 0 0 0}\end{array}$ & Total \\
\hline Weekly once & - & - & 02 & 08 & 10 \\
\hline Once in 15 days & 01 & - & 01 & 04 & 06 \\
\hline Once in a month & 06 & 06 & 10 & 12 & 34 \\
\hline Total & 07 & 06 & 13 & 24 & 50 \\
\hline
\end{tabular}

$\mathbf{H}_{\mathbf{0}}$ : There is no association between the income and frequency of purchase.

$\mathbf{H}_{1}$ : There is an association between the income and frequency of purchase.

Degree of freedom:

$$
\mathrm{V}=2
$$

Calculated value $=8.7808$

Table value at $5 \%$ significant level $=12.6$

Conclusion: The null Hypothesis hold true at 5\% significant level as the table value is more than the calculated value. Hence it concludes that there is no relationship between the income and frequency of purchasing.

\section{SUGGESTIONS}

For the long existence of health drink Horlicks Company should adopt the following strategies.

- More flavour can be introduced in order to attract the consumers.

- Increase the sales of the products at reduced price.

- More advertisement on local Television channels and local Newspaper can be given, so that consumer can get more information about Horlicks.

- The container of the Horlicks can be changed from ordinary plastic to food grade plastic.

\section{CONCLUSION}

Customer satisfaction plays a vital role for the success of a business. Consumer is a king of the market. Continuous improvement is the success of customer satisfaction of Horlicks, leads to increase in profitability. More over the respondents need to no changes other than changes in quality and price. Consumption of increase in Horlicks leads more health improvement, convenience, changing life style and increasing favour. The customer relationship with food and other everyday goods has changed dramatically not only in terms of purchasing goods but also in their consumption.

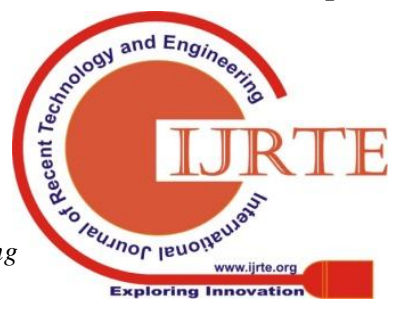


This shows that the company is effectively giving satisfaction to the customers, which leads to the success of the company.

\section{REFERENCES}

1. Dr. Vidyadar Reddy, and model Abdul Azeem 1998, "Customer satisfaction through complaint handling".

2. Dr. Raja Talluri, A study on buyer's behaviour towards complain with special reference to Vijayawada. International Journal of Multidisciplinary research and Modern Education, ISSN 2454-6116

3. Mr. S. Jamuna, K. Tamilvanan, A study on customer satisfaction towards Boost with special reference to Theni District. IOSR Journal of Business and Management. ISSN: 2319 - 7668.

4. Latour, Steven A. andNaney C. Peat (1979) Research volume 6, conceptual and methodological issues.

5. Lele M.M. and Sneth J.D. 1987, the customer is key: Gaining an unbeatable advantage through customer satisfaction.

\section{AUTHOR PROFILE}

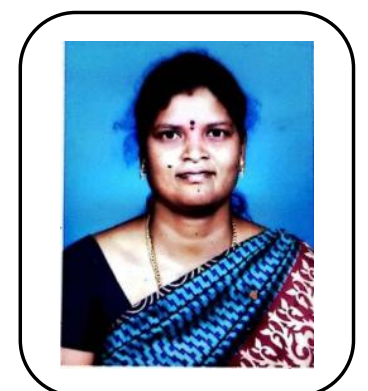

Aspiring great things is a human tendency and the genuine passion to scale greater heights exemplary ambition. This is Mrs. R. Sugumari M.Com., M.Phil (NET), M.B.A (NET)., working as an Assistant Professor, Department of Commerce (G/C.A) at Thiruvalluvar University College of Arts and Science, Arakkonam, Ranipet District, Tamilnadu. 19 years of rich and dynamic experience in teaching, Administration, Research Contribution and student counseling remarkable achievement is got the first rank in M.B.A and Received the Gold medal from honorable Governor Mr.Surjith Singh Barnala in the year 2008. Member board of studies for autonomous colleges. Served as a question setter in Various Universities. Published More than 10 papers in international journals. Besides presented more than 15 papers in the national and international conference and guiding several M.Phil scholars in commerce. 